\title{
Reform and Research of Computer Teaching in Colleges and Universities
}

\author{
Xiaosen Wen ${ }^{1}$, Le Cheng ${ }^{2}$ \\ ${ }^{1}$ Xijing University, Xi'an, Shaanxi Province, China, 710123 \\ ${ }^{2}$ Shaanxi Radio and Television Station, Xi'an, Shaanxi Province, China, 710123
}

Keywords: Computer Teaching, College Study, Teaching Reform

\begin{abstract}
With the development of modern information technology, all aspects of social life have been inseparable from the auxiliary functions of computers. To this end, the reform of computer teaching in colleges and universities should keep pace with the times and take social demand as the guide to cultivate talents in the market. This paper mainly discusses and analyzes the computer teaching reform in Colleges. It mainly involves the content of computer teaching reform in colleges and universities and the reform approach. It deeply considers the problems of computer teaching reform in colleges and universities, and guides the healthy and stable development of computer teaching reform in colleges and universities.
\end{abstract}

\section{Introduction}

At present, the rapid spread of computer technology and the rapid development of network technology have made computer teaching in Colleges enter a new era of reform. However, computer students trained in modern universities do not match the needs of relevant professionals in the social market. Many computer graduates in Colleges cannot compete for real work. Then, how to adjust the training objectives of computer talents in Colleges and deepen the reform of computer teaching in accordance with changes in market demand is an important issue facing the scientific research work of university computers [1].

Before selecting textbooks, we must first thoroughly investigate the requirements of enterprises and employers for various professional talents, and study how we can make college computer application foundation courses more suitable for social development needs, market demand-oriented, and select computer teaching materials that meet market needs. To ensure that the content of the computer course meets the professional needs, meet the needs of the employer, and form a course with professional characteristics.

Since there are certain differences in the computer foundation of college students, the implementation of stratified secondary teaching is beneficial to improve the computer application level of different levels of students and narrow the gap between students. In the actual computer teaching classroom, the level teaching is difficult to implement. You can consider the use of network resources to implement the design and research of the level teaching plan for the whole class, which is convenient for effective level teaching, paying attention to the students' practical hands-on ability and training students. Learn computer interest and self-learning skills.

Generally speaking, computer examinations mostly use paper-based examinations. The written examinations have been used for many years as a common examination system. However, with the development of the times, such examination systems are difficult to fully reflect the computer level of students. This examination method is also easy to create a group of students with strong theoretical and practical hands-on skills. To this end, some schools have begun to take the computer test, and achieved good results. We believe that the combination of the computer test and the written test can reflect the theoretical level of the students and reflect the students' hands-on ability. It is an effective computer test system.

\section{Problems in Computer Teaching in Colleges}

The computer has a very fast update speed, which makes the software facilities, hardware 
facilities and systems and other computer equipment have a high elimination rate. Therefore, in the computer teaching of Colleges, we must actually proceed and keep up with the times to enable the students. Fully understand and master the essence of computer teaching. However, in today's college computer teaching, many teaching materials are relatively old, and the speed of writing and updating the teaching materials lags far behind the development speed of computer information technology. In addition, there are unreasonable situations in setting up computer teaching courses in schools. The phenomenon of heavy theoretical light experiment is widespread. Many students need further training when they go to work in the enterprise after graduation. This is the teaching resources in Colleges. Very large waste has also caused great restrictions on the development of teaching in our country [2].

Computer science differs from other basic disciplines in that it focuses on the combination of theory and practice, and it is often more important to look at practice. In teaching, teachers should use scientific methods and innovative means to teach students in the classroom and use other resources to guide students to develop their practical skills. However, in today's college computer teaching, a single teaching method is widespread, and teaching methods are relatively backward, which makes students passively accept the knowledge instilled by teachers, instead of actively exploring knowledge, ignoring the application of advanced teaching methods.

The main task of computer teaching in Colleges is to use advanced teaching methods to cultivate students' ability of innovation and practice. However, many teachers in Colleges pay attention to the use of traditional teaching methods, such as teacher mechanical lectures, blind acceptance of students, etc. Students often learn from computers. Bored, and reduced the learning process to some extent. In teaching, we do not pay attention to the guidance of the syllabus, and we cannot use interactive and cooperative teaching methods to teach.

At present, computer teaching in many Colleges is based on test scores, and it is still in a period of exploration in the practice of training students. There is no integration with the needs of talent in today's society in the arrangement and setting of teaching objectives. Many students are not qualified in computer theory, and they are not very skilled in the operation of software and the operation of hardware. The teaching objectives limit the individual development of students and affect the overall improvement of computer teaching in China.

\section{Computer Teaching Reform and Development Strategy}

Learning is the essence and core of computer teaching. For teachers and students of Colleges, establishing a lifelong learning concept is the only way to achieve self-development and improvement. Especially in the modern society where competition is becoming fierce, the speed of knowledge update is getting faster and faster. Being able to master a set of scientific and reasonable teaching and learning methods will undoubtedly promote the improvement of teachers and students and talents themselves and also promote Colleges. In this process, all teachers and students should establish a modern teaching and learning concept, actively use diversified teaching and learning methods, and extensively engage in computer-related knowledge to improve their comprehensive skills [3].

For the purpose of classroom practice, the main place for computer teaching in Colleges is classroom. At the same time, it is also the main front for students to learn knowledge. How to use classroom teaching resources reasonably to achieve good teaching results is the current computer teachers in Colleges. In teaching, teachers should pay attention to behavioral research, and must constantly reflect on the gains and deficiencies in their own teaching; pay attention to the reform of computer classroom teaching, and strive to improve their teaching skills and teaching level. Students should use every minute and every second in the classroom, follow the teacher's footsteps, actively explore knowledge, and actively improve and absorb knowledge after class. This is also a good way to get the fastest knowledge.

At present, the basic standard for measuring computer teaching in Colleges is teachers. Therefore, if colleges want to improve their own teaching level and enhance their own popularity, they must consciously build a strong and highly qualified faculty, among them, Teachers are a good tool for 
training. In the training, it is necessary to pay attention to the improvement of teachers' professional skills, but also to change the traditional teaching concepts of teachers in the past, so that they should quickly change their roles and actively use students as the masters of classroom teaching. At the same time, it is necessary to let teachers accelerate their own transformation and development, that is, from the past experience to the current innovation, from the past education to the current professional composite talent.

With the continuous development of modern society, relying on its own strength can no longer meet the needs of social development, we must cooperate with others, actively strengthen our team consciousness, and improve in the collective and unity is the focus of development. weight. Nowadays, many Colleges have recognized the importance of teamwork and have begun to collect their work in preparation, teaching and evaluation. Through cooperation and exchange, we can not only learn from both sides' experiences, but also achieve common progress and improvement, and further promote computer reform and development in the discussions between the two sides.

In the reform and development of computer teaching in Colleges, it is a very important learning path to effectively open case analysis activities, learn from those successful experiences, and summarize those failed teachings in order to obtain rapid improvement. In the case analysis, Colleges should proceed from the reality, reasonably analyze and demonstrate the cases implemented, and actively summarize and develop new and scientific teaching methods as much as possible [4].

In the computer teaching of Colleges, the majority of teachers should constantly research and summarize in the reflection of teaching, which is conducive to improving the teaching level and professional skills of teachers. Based on this, college computer teachers should learn how to think and learn how to study in the teaching. At the same time, they should develop a good teaching habit to analyze the problem and raise the practice to the height of research as much as possible. Promote the reform and development of the computer industry in Colleges.

The time for teaching in the classroom is limited, and learning is unlimited. The computer reform of Colleges should focus on cultivating students' interest in computers and motivating students to learn actively. Therefore, according to the conditions of the school, organized and planned computer-related extracurricular activities, such as programming, web page production, animation production, PPT courseware production, etc., even in the form of competition, not only help improve students' computer Interest, but also conducive to the development of students' teamwork ability and comprehensive application ability, which is very beneficial to improve students' computer application ability, how to solve problems, and the psychological quality of encountering difficulties. .

Computer teaching in Colleges should establish the versatility and instrumental awareness of computer basic courses. The teaching content should be related to the study of professional courses. For engineering, water conservancy, information technology and other majors, the program design course can be increased. $\mathrm{C}++$ can be opened. VB, computer programming language Java and other computer courses, these courses are designed to help students develop the theoretical research and engineering design and development of the use of computers; for economic, accounting, law and other professional students, the emphasis on application ability professors It can provide practical skills such as Word, PowerPoint, Excel, web application and other practical skills, dynamic web page creation, document uploading and downloading. This is the need to study professional courses, but also the requirements of employers for idealized talents [5].

\section{Conclusion}

Today, with the rapid development of information technology, the reform of computer teaching in Colleges is an urgent task. However, the computer reform of Colleges is not a one-off process, it is a long process. As an educator engaged in computer teaching in Colleges, he should take the initiative to shoulder the heavy responsibility of computer teaching reform in Colleges and train high-quality composite modern talents for the country. 


\section{References}

[1] Zhang Hang. Discussion on the practicality of computer teaching reform in Colleges [J]. Heilongjiang Science and Technology Information, 2013 (2).

[2] Zhang Yuren. The problem of computer teaching in Colleges and the analysis of countermeasures[J]. Group world, 2011(9).

[3] Li Liang. On the Reform of Computer Teaching in Colleges[J]. Computer Education Weekly, 2013(11)

[4] Zhang Hang. Discussion on the practicality of computer teaching reform in Colleges [J]. Heilongjiang Science and Technology Information, 2013 (2): 197.

[5] Sun Hua. Exploring the reform and development of computer teaching in high schools in China [J]. China Electronic Commerce, 2012 (20): 111. 